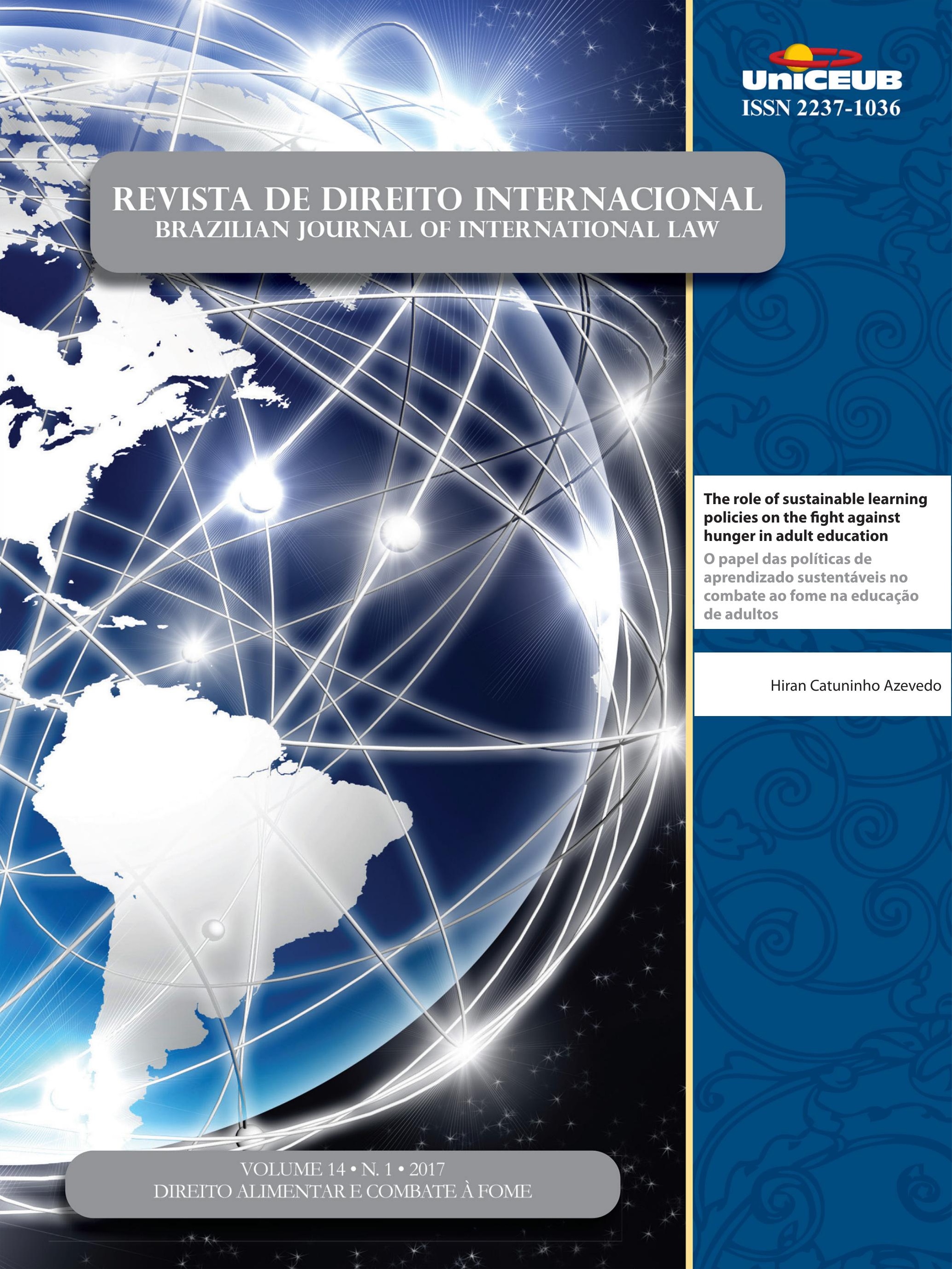




\section{Sumário}

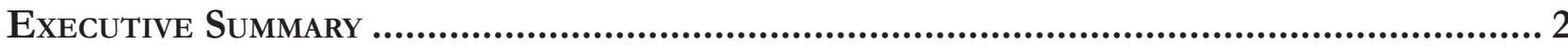

Daniel Balaban

Crônicas Sobre o Direito Alimentar e o Combate À Fome .............................................. 5

South-South Food and Nutrition Security promotion: the Brazilian experience

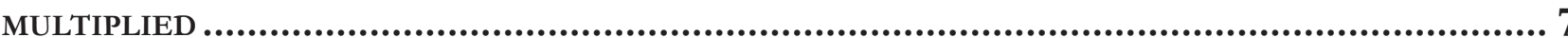

João Almino

Access to Food as a Human Right: Brazil, WFP and South-South Cooperation .......10 Carlos R. S. Milani

Dossiê temático: Direito Alimentar e Combate à Fome 13

WFP'S ROLE IN BUILDING SUSTAINABLE BRIDGES BETWEEN THE RIGHT TO ADEQUATE FOOD AND THE FREEDOM FROM HUNGER 15

Christiani Amaral Buani e Bruno Valim Magalhães

Direito humano À ALIMENTAÇÃo, (IN) SEgURANÇA ALIMENTAR E DESENVOLVIMENTO: OS DESAFios à REALIZAÇão PROGRESSIVA Na AMÉrica LATINa

Sinara Camera e Rubia Wegner

STATE'S INTERNATIONAL RESPONSIBILITY FOR THE HUMAN RIGHT TO FOOD: IMPLEMENTATION IN BRAZIL THROUGH AGROECOLOGY

Paula F. Strakos e Michelle B.B. Sanches

NegotiatiNg agRiCULtURE IN THE WORLD TRADE ORgANIZATION: FOOD SECURITY AS A NON-TRADE CONCERN.

Ana Luísa Soares Peres e Letícia de Souza Daibert

QUANDO HABITAR CORRESPONDE AO DIREITO HUMANO À ALIMENTAÇÃO

Fernanda Viegas Reichardt e Maria Elisa de Paula Eduardo Garavello 
The ROLE OF SUSTAINABLE LEARNING POLICIES ON THE FIGHT AGAINST

HUNGER IN ADULT EDUCATION.

Hiran Catuninho Azevedo

O DIREITO HUMANO E FUNDAMENTAL À ALIMENTAÇÃo ADEQUADA E À CONDIÇÃo

FEMININA NO PROGRAMA BOLSA FAMÍlIA: EMPODERAMENTO ÀS AVESSAS?

Rosalice Fidalgo Pinheiro e Laura Garbini Both

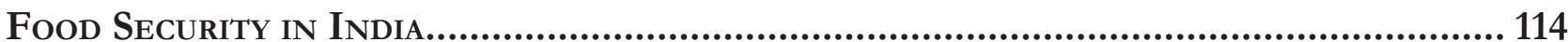

Ranjana Ferrão

SEguranÇA ALIMENTAR E A GOVERnANÇA ECONÔMICA GLOBAL

Danielle Mendes Thame Denny, Douglas de Castro, Alexandre Ricardo Machado, José Valverde Machado Filho e Gabrielle Fontes Witt

Outros Artigos.

The legal implications of the Draft Universal Declaration of the Rights of MANKIND

Catherine Le Bris

Litigating Indigenous Dispossession in THE Global Economy:

Law's Promises and Pitfalls................................................................................ 165

Charis Kamphuis

UNE DÉFINITION DU PRÉ-INVESTISSEMENT CONFORME À L'APPROCHE FRANÇAIS MAIS CONTRAIRE À L'APPROCHE AMÉRICAINE AU SEIN DES TRAITÉS BILATÉRAUX D'INVESTISSEMENTS IRANIENS

Peyman Dadras

CONFLITOS ENTRE REGULAÇÕES INTERNAS RELATIVAS À INTERNET E O DIREITO DO COMÉRCIO INTERNACIONAL: O PAPEL DA OMC PERANTE O SISTEMA DE COMPUTAÇÃO DA NUVEM ............238

Alice Rocha da Silva e Filipe Rocha Martins Soares

Prélèvement: origem, EVoluÇão e ocaso do Privilégio NAS SuCESSÕes INTERNACIONAIS NA FRANÇA

Fernando Pedro Meinero 
OS CONTRATOS INTERNACIONAIS DE FINANCIAMENTO E O CENTRO FINANCEIRO DE

Nova IorQue: CONSIDERAÇões SOBRE A AUTONOMIA DA VONTADE

Fernanda Torres Volpon

Mercosul e o Meio ambiente: ANÁlise da tUTELA REgional AMBIENTAL 284 Clarissa Ferreira Macedo D'Isep

Ainda (E uma Vez MAis) o SILÊNCIO QUe ENTOA O TRIUNFo De Lewis Carrol: A Regra N ${ }^{\circ} 42$ do Supremo Tribunal Federal

Thiago Aguiar Pádua e Bruno Amaral Machado

\section{A Natureza Jurídica do Sistema de Solução de Controvérsias da OMC} E DE SuAs Decisões: Solucionando um Imbróglio 316

Camila Capucio

Brics: Desafios do DESENVOLVIMENTO ECONÔMICO E SOCIOAMBIENTAI Magno Federici Gomes e Luís Eduardo Gomes Silva

REVER OU ROMPER COM VESTFÁLIA? POR UMA RELEITURA DA EFETIVA CONTRIBUIÇÃO DOS ACORDOS DE PAZ DE 1648 À CONSTRUÇÀO DO MODELO VESTFALIANO DE ESTADOS.

Luiz Magno Pinto Bastos Junior

Justiça de Transição EM SUA GÊNESE: A Alemanha Pós-NAZismo 378 Bruno Galindo

Quando JUlgar SE TORNa UM ESPETÁCulo: A INTERAÇão ENTRE o Supremo Tribunal Federal e a opinião pública, A PARTIR de REFlexões da LITERATURA ESTRANGEIRA

Patrícia Perrone Campos Mello

TolerânCia E refugio: um ENSAIO A PARTIR do ACORdo EU-TurQuia 425 Flávia Cristina Piovesan e Ana Carolina Lopes Olsen 


\title{
The role of sustainable learning policies on the fight against hunger in adult education
}

\author{
O papel das políticas de aprendizado \\ sustentáveis no combate ao fome na \\ educação de adultos
}

Hiran Catuninho Azevedo **

\begin{abstract}
We live in an unprecedented world of opulence, but also of extraordinary deprivation and oppression. This paper suggests the role of a sustainable education on the fight against hunger, poverty, and inequalities. If the environmental crisis is not solved, hunger cannot end, especially in underdeveloped countries and regions. Education is, more than ever, an important tool to increase the living standards. Due to sustainable educational processes, we have much more knowledge of how to solve climate problems, reduce poverty and increase food production without destroying Earth resources. Educational processes based on sustainability context also brings the opportunity to rethink the lack of collective coordination, especially among states. We are a civilization that shares the same fate, and together they can build more international cooperation and less competition, and education is a key point to rewrite the human history with no more hunger. Understand how industry and society grow and develop is essential to know how they learn and become productive, and knowledge production, a crucial point in education, already produces countries that are more able than others regarding the development of intensive sectors in state-of-the-art technology, capable of generating more income, better production and reducing their nourishment vulnerability. These effects can be shared with underdeveloped ones. Innovation has been a crucial part of the most developed economies throughout history. The rise of living standards should be attributed to the technological progress, in learning how to do things better. A sustainable educational system is a crucial support to reduce knowledge inequality between developed and underdeveloped countries and help ones with learning difficulties, able to create learning societies free from hunger.
\end{abstract}

Keywords: Education Reduce Inequalities Public Policies Sustainability Hunger Erradication

* Recebido em 31/10/2016 Aprovado em 24/04/2017

** MA in Human Sciences, Department of Human Sciences of The University of Tsukuba, Japan. E-mail: hcatuninho@gmail.com

\section{RÉSUMÉ}

Nous vivons dans un monde sans précédent de l'opulence, mais aussi de la privation et de l'oppression extraordinaire. Ce document suggère le rôle d'une éducation durable sur la lutte contre la faim, la pauvreté et les inégalités. Si la crise de l'environnement ne soit pas résolu, la faim ne peut 
pas finir, en particulier dans les pays et les régions sous-développées. L'éducation est, plus que jamais, un outil important pour augmenter le niveau de vie. En raison de processus éducatifs durables, nous avons beaucoup plus de connaissances sur la façon de résoudre les problèmes climatiques, réduire la pauvreté et accroître la production alimentaire sans détruire les ressources de la Terre. Les processus éducatifs basés sur le contexte de la durabilité apporte également la possibilité de repenser le manque de coordination collective, en particulier parmi les Etats. Nous sommes une civilisation qui partage la même sort, et, ensemble, ils peuvent construire une plus grande coopération internationale et moins de concurrence, et l'éducation est un point clé de réécrire l'histoire humaine sans faim. Comprendre comment l'industrie et de la société grandir et se développer est essentiel de savoir comment ils apprennent et devenir productifs, et la production de connaissances, le point crucial dans l'éducation, produit déjà pays qui sont plus capable en mesure que d'autres concernant le développement des secteurs à forte intensité dans l'état de la dernière technologie, capable de générer plus de revenus, une meilleure production et réduire leur vulnérabilité a la nourriture. Ces effets peuvent être partagés avec les sous-développés. L’innovation a été un élément crucial des économies les plus développées à travers l'histoire. L'hausse du niveau de vie ne devrait pas être attribuée au progrès technologique, pour apprendre à mieux les choses. Le système éducatif durable est un soutien crucial pour réduire l'inégalité des connaissances entre les pays développés et sous-développés et d'aider ceux ayant des difficultés d'apprentissage, capables de créer des sociétés d'apprentissage libre de la faim.

\section{INTRODUCTION}

Sustainable development, or the idea that societies can develop by exploiting natural resources in ways which "meet present needs without compromising the ability of future generations to meet their needs"1, has become a mantra in both policy and practice, at governmental and institutional levels, in business as much as in education. The same applies to the concept of sustainability to address the ability of creating and maintaining the conditions under which sustainable development is possible.

1 WCED, 1987, Sect. 4, Article 27
Etymologically, both the adjective ("sustainable") and the noun ("sustainability") have a long history, as they are derived from the ancient Latin verb sustinere, "to hold up, hold upright, uphold, to bear up, keep up, support, sustain"2. Sustinere is composed from tenere, "to hold, keep ..."3, and sub, "under, below, beneath, ..."4. The verb was already in use in medieval French, and derivations can be found in several Romance languages such as French (soutenir), Italian (sostenere), Portuguese (suster) or Spanish (sostener), and other languages like English (sustain). However, neither the adjective nor the noun made their official appearance in the vocabulary of environmental and social scientists until the $1970 \mathrm{~s}^{5}$, when an informal network of politicians, businessmen and scientists from the Global North (e.g., the United States of America and Europe), still active today under the name "Club of Rome", published The limits to growth: A report for the Club of Rome's project on the predicament of mankind. ${ }^{6}$

Ever since, sustainable development, and the conditions by which it can be upheld, have turned into a core value which has slowly permeated governmental and institutional thinking, in business as well as education; and it is now intrinsically linked with the ways societal problems are thought of and addressed in private and public policy. However, at times when social and economic crises have revealed the fragility of existing policies and institutions, it is imperative to consider how societal sustainability is - and could be - better integrated into adult education and learning policy, and to do so in the multi-level context of the different national, social and cultural environments in which national and transnational levels of governance interact. As a result, the very concept of sustainable development must be put under close scrutiny, drawing on concepts and understandings from different disciplines and identifying strategies and lines of action which could contribute to societal sustainability.

In this theoretical paper, it is considered the topic from the perspective of adult education and learning. Beginning by addressing the conditions under which the concept of sustainable development entered the political debate and consider how it has influenced resear-

\footnotetext{
2 Lewis and Short, 1879 , p. 1822

Lewis and Short, 1879, p. 1853

Lewis and Short, 1879, p. 1772

OED, 2016

Meadows et al. 1972
} 
ch in education. In the main part of our paper, there is an argument for rethinking its ontology. First, it is denounced the reduction of sustainable development to sustainable (economic) growth ${ }^{7}$ and consider the centrality of social justice theory to mitigate inequalities in societal development ${ }^{8}$; then it is showed that this aspect has been a long-standing matter of debate in adult education, and suggest that an awareness of social justice can contribute to understanding sustainability. Finally, it is presented a framework for conceptualising the ecology of education systems ${ }^{9}$ as a key element in creating and maintaining the conditions under which sustainable development is possible. Rethinking societal sustainability in this way can shed new light on the relationships among sustainable development, social justice and the ecology of human development, and, by extension, illuminate the role of adult education and learning policy in fostering societal sustainability.

\section{TRACING THE ROOTS OF SUSTAINABLE DEVELOPMENT}

Contemporary attention to the fact that societies, as dynamic systems, ought to take into account a number of factors to keep developing and growing can be traced back at least to the publication of The limits to growth $^{10}$. This seminal Club of Rome report was the first to present to a worldwide audience a computing model purposely created to account for the relations between diverse factors of development and simulated alternative scenarios for growth, based on available resources. Written by Donatella Meadows, an American environmental scientist, Dennis Meadows, an American scientist who construed the model on which the book stands, and Jørgen Randers, a Norwegian scientist devoted to climate issues, The limits to growth calculated the consequences of rapid world population growth for the finite resources available. In brief, as one of the authors clarifies in hindsight,

Limits to Growth said that the environmental impact of
buman society did increase from 1900 to 1972 because of
growth in population size and growth in the environmental
impact per person. In other words, the ecological footprint of
humanity became heavier because of growth in the number of

7 Seghezzo, 2009

8 Rawls 1971, 1985, 1993, 2001

9 Bronfenbrenner, 1976

10 Meadows et al. 1972 bumans, and because of growth in the amount of resources consumed and pollution generated per person per year. ${ }^{11}$

Thus, The limits to growth drew attention to the fact that natural resources are physically limited and the ecological footprint of humanity would not be able to continue at the same speed and to the same extent as in the past, if the planet and its inhabitants were to survive the (then) present.

Critiques, rejections and positive re-assessments of The limits to growth at a 40-year distance notwithstanding $^{12}$, sustainable development has been intrinsically associated with the exploitation of natural resources, including oil and agricultural land, or the ecological footprint of humanity, and has attracted controversial attention from activists, scientists, politicians and inter-governmental organisations. This is also thanks to the World Commission on Environment and Development (WCED), created in 1983 by the United Nations (and dissolved in 1987), which published another seminal report, Our common future. ${ }^{13}$

It was in Our common future that the concept of "sustainable development" was first used to address a type of growth strategy which was not disconnected from environmental concerns. As a result, the concept rapidly diffused across the world, also under the influence of the United Nations' World Summit on the Environment, held in Rio in $1992^{14}$. Within a few years, this led to the signing of an international treaty on climate change, the Kyoto Protocol of $1997 .^{15}$

\section{Sustainable DEVELOPMENT AND RESEARCH IN EDUCATION}

The growing political attention to sustainable development has not gone unnoticed in education, partly thanks to the United Nations Educational, Scientific and Cultural Organization (UNESCO). In fact, in the same year the Club of Rome published The limits to growth, UNESCO released its report Learning to be: The world of education today and tomorrow ${ }^{16}$. A key "planning

\footnotetext{
11 Randers, 2005, section Limits to Growth 1, paragraph 1

12 Baldi, 2011

13 WCED, 1987

14 UM, 1992, a, b

15 UM, 1998

16 Faure et al., 1972
} 
document" in the history of UNESCO ${ }^{17}$, and a landma$\mathrm{rk}$ in the global history of adult education ${ }^{18}$, the report addressed the danger besetting the environment and, with it, human co-existence as an educational challenge.

\begin{abstract}
Technological development has enabled man to solve many problems, but it has had harmful effects on a number of aspects of contemporary life. All over the world, it contributes to environmental deterioration [...]. It is not only man's environment but - in the near future - bis very fate which may be threatened, and he has already begun to suffer. Rapid changes are winding up tension in people, increasing insecurity, nervous disorders, antisocial behaviour, delinquency and criminality [...] Stimulating awareness of such dangers is a demanding new task for education, but particularly appropriate to it for many reasons and, too often, one that is much underestimated. ${ }^{19}$
\end{abstract}

Three decades later, the United Nations renewed its efforts in highlighting the role education can play in mitigating environmental peril through launching the United Nations Decade of Education for Sustainable Development (DESD) 2005-2014. UNESCO reiterated its commitment to this strategy in the Bonn declaration by stating that

\begin{abstract}
through education and lifelong learning we can achieve lifestyles based on economic and social justice, food security, ecological integrity, sustainable livelihoods, respect for all life forms and strong values that foster social cohesion, democracy and collective action. ${ }^{20}$
\end{abstract}

These policy initiatives emphasised participatory and critical teaching and learning methods designed to motivate and empower learners to change their behaviour - and take action - for sustainable development to be incorporated in policies. Accordingly, for the most part, educationalists have first and foremost focused on how teachers for different subjects work with the concept of sustainability in the classroom ${ }^{21}$, or on how subjects like sustainability or health could be included more fully rather than as merely "residual" issues - in school curricula, so as to promote "healthy and sustainable actions in their students" 22 . Moreover, educationalists have also examined the challenges education for sustainable development poses in terms of justice, environment, human rights and citizenship; and the ways higher education institutions as well as social or environmental professional

17 Singh, 2011

18 Milana, 2016

19 Faure et al., 1972, pp. 99-101

20 UNESCO, 2009, para 5

21 Myers, 2012

22 Simovska and Mannix McNamara 2015, p. vii and education organisations treat and respond to them ${ }^{23}$. Sometimes - if rarely - the above strands of literature extend attention beyond the theory which informs educational praxis at institutional or individual level, to critically examine education policy development in connection with social, economic and environmental crises.

Rather different is the case with those studies which explicitly address the challenges sustainable development poses at the institutional level, including in terms of adopted pedagogies. These studies question the very purpose and nature of educational institutions and how they respond to the policy agenda on sustainability ${ }^{24}$ by teasing out social-environmental relations. What emerges is a range of transformative approaches to re-thinking teaching and learning of and about the relations between environmental degradation and social conflicts ${ }^{25}$ or ideas for re-ordering environmental priorities "to think more carefully about pedagogy and how under global and postcolonial conditions, theory can and should inform the practice of education for a sustainable future"26.

At macro level, growing attention is also being given to the effects of social and economic crises, migration flows or climate change on the sustainable development of contemporary societies and lifestyles. Informed, for the most part, by a "capability approach"27, these studies question predominant paradigms in policy debates on human development. They place an emphasis on the "substantive freedoms" which people value in order to grow old, participate in economic exchange, or engage in political action, rather than on utilitarian aspects or simple access to resources. This way of thinking about human and societal well-being is also found in investigations of lifelong learning policies which contest conventional thinking about the links between education, work and the economy ${ }^{28}$, or in studies on migrants' adaption to new socio-political and cultural environments which question the conditions for full realisation of a good life in the host country ${ }^{29}$. This strand of literature often foresees new policy directions and prompts ideas for "reversing policy-making optics" ${ }^{30}$, for valuing

23 (McFarlane and Ogazon 2011)

24 Blewitt and Cullingford, 2004

25 Misiaszek, 2012

26 Matthews, 2011, p. 236

27 Sen, 1989; Nussbaum and Sen, 1993; Nussbaum 2000

28 Brown, 2013

29 Webb, 2014

30 Livingstone, 2012 
the richness of available knowledge, and for avoiding its waste. Moreover, it calls for policies and programmes which focus on challenging the problems which have led to the current crisis, and encourages economic and ecological change for global sustainable development.

In the same line of thinking, it is proposed a challenge the mainstream conception of sustainable development on which adult education and learning policy draws, including underlying ideas about (economic) growth and prosperity.

\section{How a sustainable education Can SUPPORT THE HUNGER ERRADICATION?}

The sustainable development should not be based only on the fight against poverty. It must also include environmental security and reducing inequality. In 2015, new Sustainable Development Goals were set, because Millennium Development Goals were focused on reducing extreme poverty. In the last 15 years, there was a strong decrease in the number of miserable. Although the number of people in this condition has fallen by half compared to 1990 data, it was not enough to eliminate extreme poverty. On the environmental front, countries made a commitment to stabilize carbon emissions in 1992, and 24 years after, it did not happen yet. Now the danger is growing ${ }^{31}$. The three main threats: climate, biodiversity, and desertification have not been adequately solved yet, then climate change and loss of ecosystems are far worse than they should be ${ }^{32}$. We will not solve the climate issue if we do not solve the problem of increasing poverty in the world, and the reverse is true ${ }^{33}$. Especially in the context of Industry 4.0, a reality we have begun to experience routinely, that means a society with a strong presence of digital technologies, mobility and people connectivity, where the differences between men and machines dissolve and which central value is the information ${ }^{34}$, sustainable educational processes are opportunities to take effective actions against these problems.

This process has occurred in substantive scale and speed, affecting overwhelmingly all dimensions of

31 Sachs, 2015

32 UNEP, 2016

33 UNEP, 2016

34 Castells, 2010 our lives and the way we relate to each other ${ }^{35}$. As an effect, industry 4.0 opens a world of possibilities and risks. Therefore, it is an opportunity to review the relationship between humankind and the technologies we created ${ }^{36}$. We should dominate them, instead of being dominated or use it to oppress our pairs. New technologies should be used to assure everyone opportunities to create wealth and share prosperity, providing decent living conditions for people, whoever and wherever they are. They should ensure the promotion of human dignity to ensure everyone the material conditions for the care of their basic needs and their full potential development, regardless any kind of distinctions, where the hunger erradication, the end of malnourishment and ensure food safety are central points ${ }^{37}$.

If the environmental crisis is not solved, poverty cannot end. Africa, for example, is extremely vulnerable to climate change, since it is already very hot and high temperatures threaten crops. There are also water shortages in many places and high diseases rates. All these environmental crises, if not controlled, will undermine long term development especially in Africa, Asia, and Latin America. If poverty is not confronted, the population of Africa, for example, will continue to grow uncontrollably, even reaching four billion by the end of the century; nowadays are a billion. Populational explosion can exacerbate poverty, undermining biodiversity and the water supply in these continents. For all these reasons, environmental control, including the control of climate change is an integral of ending extreme poverty ${ }^{38}$. Development includes the ability of people to live the life they want to lead without the constraints of poverty, and their subsequent factors, such as hunger, and it occurs not only from a lack of food but from inequalities built into mechanisms for distributing opportunities. In famine, development is menaced, while poorest people still starved because they cannot do anything. They do not control the functioning of nourishment, nor the capability to escape morbidity ${ }^{39}$.

Human action is contributing to global warming. The consequences if greenhouse effect gases are not controlled will be very dangerous ${ }^{40}$. The type of drou-

\footnotetext{
35 Castells, 2010

36 Castells, 2010

37 Sachs, 2015

38 Sachs, 2015

39 Sen, 1981

40 Sachs, 2015
} 
ght that the city of São Paulo faces today will spread around the world. California is under threat, Middle East live with droughts ${ }^{41}$. They will generate social conflicts. The drought in Syria contributed to the outbreak of civil war. Syria faces one of the longest periods of low rainfall in its history, which led to the displacement of more than 1 million people, rising food prices, the social unrest and eventually contributing to war ${ }^{42}$.

Due to industry 4.0, we have much more knowledge of how to solve climate problems - and without education we could not get through this revolution. It is also an opportunity to rethink the lack of collective coordination, especially among States, which many times are hidden behind the economic competitiveness claim. We need to overcome it, as we see events that never happened before. Climate changes and populational increase have created new standards that must be understood. If there is no collective cooperation taking account population dynamics and climate change, crises are inevitable and put at risk Earth existence ${ }^{43}$.

Technology is, more than ever, an important tool to live in a better world ${ }^{44}$. We must consider how educational processes can build revolutions such as industry 4.0, and its power to reduce inequalities and change our lives. Many people, communities, governments and companies are always connected, while in Sub-Saharan Africa and South Asia 1.5 billion do not have access to reliable telecommunications services. It can make our cities, industries, and plantations smarter, cleaner and safer. With the infrastructure provided by industry 4.0, energy systems may be more efficient, with less waste and carbon emissions. It also allows a better preparing to deal with climate change, such as storms, sea level rising and high temperatures, as well as having more spread and reliable transport and feeding systems, with better vehicles and food sharing instead the high concentration of private vehicles and food waste ${ }^{45}$.

The idea that we need a stagnant economy to do not harm the environment is wrong. Humanity likes progress, and poverty reduction depends on it ${ }^{46}$. Industry 4.0 is the perfect opportunity to unlink economic growth from nature destruction. Some say that combi- ning both is not possible, as the use of natural resources has grown in recent decades and we cannot do it without them. It is not wise just to look back, but forward as well. Industry 4.0 creates new technologies, which are cheaper and conserve ecosystems. It is crucial build a strategic and planning cooperation. Especially for poor countries, economic growth is a matter of life or death, and everyone should have access to these technologies 47. Then, sustainable educational processes may engage people, businesses, and governments into this collective convergence.

Industry 4.0 is a hope to develop technologies that allow us to grow consuming fewer fossil fuels, which represents $80 \%$ of our energy use ${ }^{48}$, including real possibilities to make biofuels, wind and solar energy economically advantageous in large scale. The initiatives occurred so far are interesting. There are GPS based electric vehicles automatically piloted that are more energy efficient than the driven by humans. Smart cyber-physical systems make industries more sustainable and competitive, such as biofuels production, with less waste, respecting areas for food, nature and native communities. The improvement of these technologies is the perfect meaning of development - the capabilities of human realization become extensions of our own freedoms. It is an advance on the freedoms we enjoy ${ }^{49}$.

Another challenge in this new scenario is to maintain social achievements and stimulate the increase of productivity with investments in education and innovation, to obtain productivity gains and job creation. New social pacts are important to turn into opportunities this moment of economic disruption ${ }^{50}$. It is necessary to build new alliances to unite people and enable conditions to create a new historical cycle. Industry 4.0, moreover, follows the same trend of its earlier industrial revolution: its hyperconnected nature, at real time. It influences significant changes in production and consumption systems, with extensive use of artificial intelligence. With the end of differentiation between men and machines, there is a new breakdown in the supply chains and business interactions models, which consumers act as producers ${ }^{51}$. In this process, it is expected

\begin{tabular}{ll}
\hline 47 & Sachs, 2015 \\
48 & UNEP, 2016 \\
49 & Sen, 1999 \\
50 & World Economic Forum, 2016 \\
51 & Castells, 2010
\end{tabular}


that more than 7 million jobs will be lost ${ }^{52}$. We have not overcome the adverse effects of the previous industrial revolutions yet, such as high levels of misery, poverty and inequalities, the usual intranational and international conflicts of great destructive capacity and the fast degradation of Earth resources, generated by the relentless wealth accumulation pursuit in a worsening globally scaled competition ${ }^{53}$, problems which a sustainable education is committed to overcome. We are the first generation that can end poverty, but the last one that can save our planet.

All the previous industrial revolutions started in developed countries, arriving late to underdeveloped. The richest countries citizens started to think their economies based on innovation. Innovation has been a crucial part of the most developed economies throughout history ${ }^{54}$. The rise of living standards should not primarily be attributed to the accumulation of capital, but to technological progress, in learning how to do things better ${ }^{55}$. While part of productivity increase reflects the dramatic discoveries impact, much of it has occurred due to small and gradual changes ${ }^{56}$. Thus, it makes sense to focus attention on how societies learn - including how they learn to learn ${ }^{57}$. As its previous industrial revolutions, industry 4.0 brings a new cognitive model to mankind, especially related to wealth creation ${ }^{58} 59$.

Reduce knowledge inequality and help countries with learning difficulties are sustainable development, and for its based education central elements. Understanding how industry and society grow and develop is essential to know how they learn and become productive, and knowledge production, the epicenter of industry 4.0, differs from the consumer goods production. Furthermore, we must consider the subsequent division between developed and undeveloped countries, not just because of the resources or output gap between them, but also of knowledge ${ }^{60}$.

Industry 4.0 already produces a new division of labor, which some countries are more able than others

52 World Economic Forum, 2016

53 Hobsbawm, 1962, 1975, 1987, 1994

54 Stiglitz and Greenwald, 2014

55 Solow, 1956

56 Stiglitz and Greenwald, 2014

57 Arrow, 1962

58 Hobsbawm, 1962, 1975, 1987, 1994

59 Stiglitz and Greenwald, 2014

60 Stiglitz and Greenwald, 2014 regarding the development of intensive sectors in state-of-the-art technology, capable of generating more income, better jobs and reducing their external vulnerability. In national level, those with higher qualifications find higher wages and greater stability opportunities while the others will not find work or will be restricted to more flexible and less paying occupations, such as temporary and part-time jobs. These asymmetries among countries and social groups tend to reproduce indefinitely. Market economies alone typically do not produce and transmit knowledge efficiently, making the richest, richer, and the poorest, poorer, in a circular and cumulative process ${ }^{61}$.

A sustainable education may act as a systemic intervention mechanism, result of essential efforts to allow the poorest and middle-income countries achieve the same level of the developed ones. Thus, it must be the result of more cooperation and less competition among countries, being the union of resources in favor of a civilization that shares the same fate, noble values that converge into a consensus capable of creating synergies and enable an effective and efficient system of international cooperation, given the reluctance of mankind to learn from the historical lessons and the destructive power of our actions. This way, a sustainable education supports substantial progress on many fronts, especially to achieve the necessary reforms to overcome underdevelopment structures.

It can also take an active role in resource allocations to effectively reduce and eliminate those asymmetries, helping "latent economies" to learn the same way of developed ones. With this privilege, the benefits of learning, including the necessary institutional development to the success of these countries can spill over other economic activities ${ }^{62}$. Create learning societies is crucial to increase living standards, and the importance of learning by doing is emphasized ${ }^{636465}$. The only way to learn what is needed for food production growth and food security development is to having an sustainable education, especially in the context of industry 4.0, where the production culture will be crucially based on information. One of the main virtues of an economy is its ability to innovate, and conventional policies focu-

61 Stiglitz and Greenwald, 2014

62 Stiglitz and Greenwald, 2014

63 Arrow, 1962

64 UNESCO, 2015

65 Stiglitz and Greenwald, 2014 
sed on short-term efficiency may be undesirable, if they take a long-term perspective of innovation and learning ${ }^{66}$. This is especially true for developing countries and emerging markets. The sustainable development goals, as its based education, supports the implementation of strong incentives policies to create a fair competition and inclusive production, not only in the area of qualification and professional training of workers for the use of new technologies, but also giving priority to investment in research and development for underprivileged communities, do not allowing them to become mere technology and food consumers, but producers as well. Another supported key point is the development of high technology sectors, able to develop and disseminate innovations that benefit the economy and raise the living standards of humanity, including the improvement of food safety, production and distribution.

\section{Questioning SUSTAINABLE DEVELOPMENT FOR SOCIAL AND INTERGENERATIONAL JUSTICE}

The concept of sustainable development has been primarily associated with environmental concerns. Nonetheless, these concerns have never been entirely independent of economic matters. Underlying the original claim that natural resources are physically limited and that the ecological footprint of humanity could limit growth was a more subtle assumption about "endless economic growth (in economic value) as long as that growth is not associated with growing physical impacts (e.g., in resource use or pollution output)" ${ }^{97}$. Such an ontology - the encouragement of economic growth has strongly conditioned development worldwide, and it remains a source of inspiration for neoliberal reforms of economic and social systems, including education, at both national and international levels.

The same ontology has given rise to the idea of "corporate sustainability", a strategic approach to business that focuses attention on how a company works in its social, cultural and economic environment. The "triple bottom line" was theorised as a model for companies to fully account for the cost of doing business. The first bottom line is a traditional measurement of corporate profit (i.e. the balance between profit and

66 Schumpeter, 1942

67 Randers 2005, Introduction, paragraph 5 loss), the second bottom line measures the degree to which a business has been socially responsible throughout its operations, and finally, the third bottom line also calculates the extent to which the company has acted responsibly towards the environment ${ }^{68}$. This way of thinking about sustainable development in terms of economic growth has led to the model (and slogan) "People, Planet, Profit", where people refers to society at large, planet to the natural environment, and profit to economic and financial prosperity ${ }^{69}$. In principle, triple bottom line thinking represents a major revision of the rationality of business activity. Throughout the history of capitalism, profit has been companies' main priority. Consequences for people and the planet were seldom given serious attention - except when they began to undermine profitability. The triple bottom line principle in business cannot provide sustainability at the societal level, but it can be an important contribution, if it is respected and actually implemented.

However, examples of companies seriously pursuing the triple bottom line approach remain scarce. Moreover, the social and economic crises which have hit individual countries (e.g. Greece) or entire regions (e.g. Europe), over the past decade have clearly shown the limits of such principles. Analysis of governments' responses, five years into the latest global financial crisis, pinpointed a renewed emphasis on individual skills, at least in the Global North, as the panacea "to work through the crisis and reposition the national economy for a post-crisis world" ${ }^{70}$.

Lucas Seghezzo, a critical voice from the Global South, has challenged the oversimplified model of thinking about sustainable development as (potentially) endless economic growth in terms of "People, Planet, Profit", and proposed an alternative model. Seghezzo questions the definition of sustainable development as the use of natural resources in ways that "meet present needs without compromising the ability of future generations to meet their needs" ${ }^{71}$. He argues that this approach is essentially anthropocentric (human-centred) and posits people as undifferentiated members of society, the planet as a mere geographical space, and profit as a short-term measure of the economic value of human actions.

\begin{tabular}{ll}
\hline 68 & Elkington, 1997 \\
69 & Fisk, 2010 \\
70 & Brown, 2013, p. 690 \\
71 & WCED, 1987, Sect. 4, Article 27
\end{tabular}


He further argues that the "People, Planet, Profit" approach emphasises the extrinsic value of natural assets for increasing the stock of "man-made" capital while discharging the intrinsic value of natural resources. Consequently, economic reasons are overestimated at the expense of equity when the links between growth and poverty alleviation or income redistribution are debated, and often "the environmental costs of economic activity are borne by the poor, by future generations, or by other countries" ${ }^{72}$. Moreover, both space and time are often mistreated in sustainability indicators, because "conceptions of time, as notions of space and territory, can differ greatly in different cultures and at different historical moments", and as such hold "an important role in the way we perceive and define nature" 73 . Along this line of argumentation, therefore, Seghezzo has revisited the unidimensional triangle composed by "People, Planet, Profit" and proposed an alternative ontology which integrates the territorial, temporal and personal aspects of development.

To illustrate this framework, I propose a sustainability triangle formed by "Place", "Permanence", and "Persons" [...]. In such a triangle, it is possible to distinguish five dimensions: Place contains the three dimensions of space $(x$, $y$, and z), Permanence is the fourth dimension of time ( $t)$, and the Persons corner adds a fifth, individual and interior, buman dimension (i). Place and Persons, the base of the triangle, represent "real", objective and concrete things that exist in the present time. Permanence, which is located in the upper (or the farthest) corner, is a more "ideal", abstract and subjective projection of events from the other corners into the future. $^{74}$

The general character of Seghezzo's proposed framework shows how difficult it is to develop approaches to sustainability which transcend both the anthropocentric presuppositions and the abstract logic of economics. But the venture in itself is important. And it sheds a new and different light on the links sustainable development holds with social justice, including inter-generational aspects.

The concept of social justice owes considerable debt to the extensive work of American philosopher John Rawls on the theory of justice and a framework for democratic society from the viewpoint of political philosophy ${ }^{75}$. The theoretical backdrop for this political conception of social justice builds on a few assump-

72 Arrow et al. 1995 , p. 92

73 Seghezzo, 2009, p. 546

74 Seghezzo, 2009, p. 547

75 Rawls, 1971, 1985, 1993, 2001 tions. First, that a society is democratic when regulated politically and socially, hence the principle of justice has the scope to specify the "fair" terms of social cooperation, and regulate social and economic inequalities. Second, it also assumes that although in such a politically plural society citizens may adhere to different religious, philosophical, moral etc. doctrines, it is still possible to reach social unity by agreement on basic principles of political justice.

Rawls' theory of justice as fairness builds on hypothetical and ahistorical positions, depicting a society at "point zero", before some institutions gain bargaining advantages as a result of social and historical tendencies which have arisen over time. But it is precisely through recognising the existence of social and historical tendencies which produce unfair social relations that the concept of justice gains relevance - in addressing what would otherwise inevitably result in social inequalities. In fact, Rawls' theory also assumes that at point zero in the development of democratic societies all citizens are equal, as they all have a minimum degree of moral power, or the capacity to understand, apply, and act from the principle of justice as fairness, as well as the capacity to have, revise and pursue the public good. At the same time, all citizens are also free, because they can conceive of themselves and others as having a minimum degree of these moral powers.

\begin{abstract}
Once we view a democratic society as a fair system of social cooperation between citizens regarded as free and equal, what principles are the most appropriate for it? [...] by what principles are differences [...] in life prospects [...] made legitimate and consistent with the idea of free and equal citizens in society seen as a fair system of cooperation? ${ }^{76}$
\end{abstract}

In response to the above queries, two principles of justice as fairness emerge. The first states that "each person has the same indefeasible claim to a fully adequate scheme of equal basic liberties, which scheme is compatible with the same scheme of liberties for all" ${ }^{77}$. Basic liberties are, in fact, essential for developing and exerting the moral power mentioned above. The second principle adds that "social and economic inequalities are to satisfy two conditions: first, they are to be attached to offices and positions open to all under conditions of fair equality of opportunity; and second, they are to be the greatest benefit of the least-advantaged members of society (the

76 Rawls 2001, pp. 39-40

77 Rawls 2001, p. 42 
difference principle)" ${ }^{78}$. Therefore, if the first principle assumes that citizens should have an equal chance to influence policy and gain authority irrespective of their economic and social conditions, the second principle clarifies that certain requirements must be imposed on the basic structure of society to guarantee fair equality of opportunity. In other words, unequal social and economic treatment is "fair" only when it favours greater benefits for the least privileged members of society.

Social and economic crises, migration, climate change and biodiversity underline the urgent need to link social justice concerns to the sustainability of societies and lifestyles - and for education policies which can contribute to this. It is suggested below that a critical engagement with adult education - and in particular with a 20th-century social theorist whose thought emerged in adult education - can contribute significantly to the understanding of sustainable development and inter-generational justice.

\section{Adult education: CUltural tensions and SUSTAINABILITY}

Marcus Singer ${ }^{79}$ has argued that Rawls' principle of fair equality of opportunity, "or at any rate something closely resembling it", together with "an antecedent of the difference principle", play "a prominent role in R. H. Tawney's Equality" ${ }^{80}$. Singer supports his argument with quotes from the book like these ones:

\footnotetext{
Inequality of power is tolerated, when the power is used for a social purpose approved by the community, when it is not more extensive than that purpose requires, when its exercise is not arbitrary, but governed by settled rules, and when the commission can be revoked, if its terms are exceeded. $[. .]^{81}$

No one thinks it inequitable that, when a reasonable provision has been made for all, exceptional responsibilities should be compensated by exceptional rewards, as a recognition of the service performed and an inducement to perform it $[\ldots]$. What is repulsive is not that one man should earn more than others [...]. It is that some classes should be excluded from the heritage of civilization which others enjoy [...] What is important is not that all men should receive the same amount of pecuniary income. It is that the surplus resources of society should be so husbanded and applied that it is a matter of minor significance whether they receive it or not ${ }^{82}$.
}

78 Rawls 2001, p. 43

79 Singer, 2003, pp. 81-82

80 Tawney, 1964 [1931]

81 Tawney, 1964 [1931], p. 17

82 Tawney, 1964 [1931], pp. 17
In the context of the present paper, Tawney's argument is significant not only for its own merits (to which we shall return), but because of who wrote it. R. H. (Richard Henry) Tawney was an English economic and social historian, and a social philosopher; he was also a leading advocate of working-class education, a lifelong member of the Workers' Educational Association (WEA) ${ }^{83}$, one of its very first tutors (and, at the time he wrote Equality, its President). Barry Elsey described him as the "patron saint of adult education" His commitment to the WEA encompassed not only a belief in the importance of education for workers (and their families), but also in the importance of democratic decision-making in education, and of education's role in building and strengthening a democratic society. While Tawney's case matters in relation to fairness, social justice and equality, our focus here is on its implications for societal sustainability. In the quotation above, he wrote not only about, in Rawls' wording, "offices and positions [being] open to all under conditions of fair equality of opportunity" 85 , but of no class being "excluded from the heritage of civilization which others enjoy" ${ }^{86}$. This was a consistent theme in Tawney's thought: he had argued as early as 1914 that working people should not be "excluded from the common heritage of civilization", from which all men and women, irrespective of their occupations are equally capable, as human beings, of deriving spiritual sustenance ${ }^{87}$. This points to the role of common culture in his understanding of social justice, and to his view of education and culture as shared not only by people alive today, but by those in the past and in the future.

\section{Education, as I see it, though it is much else as well, is partly, at least, the process by which we transcend the barriers of our isolated personalities, and become partners in a universe of interests which we share with our fellow-men, living and dead alike. ${ }^{88}$}

As our earlier quote from Learning to be ${ }^{89}$ on the social consequences of rapid technological development suggests, education has often been accorded a key role

83 The Workers' Educational Association (WEA), still offering courses today, was founded in 1903 as "The Organisation for Education of Working Class Men" by Albert Mansbridge. For more information, see WEA, 2013.

84 Elsey, (2001, p. 49)

85 Rawls, 2001, p. 43

86 Tawney, 1964 [1931], p. 112-113

87 Tawney, 1966a [1914], p. 76

88 Tawney, 1966b [1953], pp. 87-88

89 Faure et al. 1972 
in establishing sustainability, including social justice, in human lives and societies. Moreover, adult education has often been deeply connected with radical social and political movements - for democratisation, citizenship etc. Tawney's concept - and its interaction with adult education - provides an example of this, but also of the tensions involved in the struggle for social justice.

It is a truism that, in Europe at least, from the Second World War until the 1970s the links between adult education and social democratic (or socialist) welfare states were close. However, they incorporated a paradox. The political change involved in establishing a welfare state would widen access to cultural goods. Adult education was a beneficiary of this, in part because it was a cultural good, or at least a mechanism by which cultural goods could be shared more widely. "Cultural goods" is of course an ambiguous term; it assumes that elite culture can be parcelled out, distributed - and still retain its value. But it is exactly this ambiguity which made it possible for adult education to become the beneficiary of redistribution through taxation and the state provision of welfare.

Many 20th-century adult educators pursued a simultaneous valuing of "culture" (in the sense of "high culture") and a critique of the existing social, political and economic order. This is especially marked in the work of social movement adult education, one of whose objectives was always to open culture up to the masses but at the same time a critique of the social order was a central motivation and rationale in workers' education throughout the 20th century. The tensions between claiming an elite culture for the people and seeking to change the social order often went unresolved. Tawney, for example, argued that adult education should be "maintained not in order to enable intellect to climb from one position to another, but to enable all to develop the faculties which, because they are faculties of man, are not the attributes of any particular class or profession of men"90. An official report which he (largely) authored mentioned this explicitly. In order to obtain higher education,

it must not be necessary for workpeople to leave the class in which they were born. This is a point to which we attach the greatest importance. [...] [W] e attribute part of the failure of Higher Education among them [the working classes] in the past to the feeling that by means of it their ablest members were being removed to spheres where they would not

$90 \quad$ Tawney, 1966a [1914], p. 77 be available for the service of their fellows. What they desire is not that men should escape from their class, but that they should remain in it and raise its whole level ${ }^{1}$.

This was, of course, both a very radical perspective on social order and a very conservative one. It promised equal access for all to society's cultural goods, while being careful not to destabilise the economic division of labour. For Tawney, politics and education would mean fracturing the links between the division of labour at work and the unequal allocation of rewards. Many of the Oxford academics for whom he wrote the report in 1908 no doubt saw things through a rather different lens: "civilization" would be preserved, but its benefits would be spread to the "great unwashed". Natural social hierarchies would remain undisturbed, but with fuller access to culture and education, the lives and social roles of ordinary people would be more fulfilling.

In the event, welfare states typically encouraged adult education along these lines. But the tension between distribution of well-defined (elite) cultural goods to the working class and the involvement of working-class people in reshaping the character and significance of cultural goods often re-emerged in the institutionalised forms of adult education established by the welfare state.

This tension is one of the challenges confronting ideas about sustainable policy and practice in adult education. It has often contributed to a dual understanding (and organisation) of adult education as either individual consumption of cultural goods or individual "upskilling" through predominantly vocational programmes. The first form does not challenge the class basis of elite culture, while the second form does not challenge the capitalist basis of careers and work organisation. It is, after all, part of the business of adult education both to appreciate and to challenge established knowledge and values. Our argument is that while such tensions are inherent in adult education, it is also democratic practices generated in and through adult education which are best able to address them in developing sustainable policies and practices.

\section{The ECOLOGY OF EDUCATION}

In a wider sense, the concepts of sustainability and sustainable development may also be applied more di-

91 WEA and the University of Oxford, 1909, p. 50 
rectly to educational systems, the processes they frame and how they relate to society. This involves questions of balance between the structure, institutions and workings of educational systems as well as balance in the interaction between these systems with different elements and groups in society.

Sustainability, and by extension sustainable development, in this sense may be informed by the concepts of ecology and ecosystems. This is the study of interactions among organisms and their environment. These interactions are often conceptualised as ecosystems with dynamically interacting parts, including organis$\mathrm{ms}$, the communities they make up, and the inanimate components of their environment. The part of ecology most relevant to education is human ecology, which studies the relationship between humans and their natural, social and constructed environments.

A key contribution to developing an ecological approach to education and learning has been provided by Urie Bronfenbrenner (1979). His background was in developmental and social psychology, but he became increasingly critical of psychological research which tended to focus too much on behaviour in single institutional contexts like the family or the school. His "experimental ecology of education" ${ }^{92}$ was a call for a type of educational research which tries to represent as fully as possible the ecosystems at different levels in which education and learning are embedded. He argued that whether and how people learn in educational settings depends on the relations between the characteristics of the learner and his or her context in each of the principal life environments like home, school or the workplace, but also on the relations and inter-connections which exist among these life environments.

Bronfenbrenner conceptualises the ecological environment "as a nested arrangement of concentric structures, each contained within the next" ${ }^{\prime 93}$. There are four such structures, which Bronfenbrenner calls "systems":

- Micro-systems are the immediate settings containing the learner, for instance the home, the daycare centre, the classroom, the workplace.

- Meso-systems are the interrelations among the major life-settings of a learner at particular points in his or her life.

92 Bronfenbrenner, 1976

93 Bronfenbrenner, 1976, p. 22
- Exo-systems are extensions of the meso-syste$\mathrm{ms}$, embracing the formal and informal social structures' influence or impact on the immediate life-settings. Examples are the world of work, the neighbourhood, mass media, agencies of government.

- Macro-systems are the overarching institutions of culture and society, such as the economic, social, educational, legal, and political structures and systems.

This conceptual framework reflects Bronfenbrenner's background in psychology; it moves from the learners' immediate surroundings outwards to broader contexts and structures of society, and analysis becomes more abstract at the exo- and macro-system levels. As Bronfenbrenner argues, this is partly due to the fact that (in the mid-1970s) too little empirical research on learning and education had in fact tried to capture interactions and influences at these levels; but also reflects the fact that he had based his comprehensive overview of existing knowledge largely on psychological research. Redefinition of the psychological concept of human development was another main aim of his ecological approach; he held that rather than being seen as a process of inner growth, individual development should be defined as "the person's evolving conception of the ecological environment, and his relation to it, as well as the person's growing capacity to discover, sustain, or alter its properties" ${ }^{94}$.

Bronfenbrenner's ecological approach was not only an attempt to overcome limitations in research on human development; it also reflected a critical assessment of developments in society, especially an increased institutionalisation of different life settings, which undermined the interconnections between them. One example is that schooling increasingly takes place in large and standardised institutions, while the links between schools and other micro-systems in children's lives become increasingly tenuous. For Bronfenbrenner this meant that schools became "breeding grounds for alienation" 95 , and he argued that this development threatened basic qualities of society.

No society can long sustain itself unless its members have learned the sensitivities, motivations, and skills involved in assisting and caring for other buman beings. Yet the school, which is the setting carrying primary responsibility for preparing young people for effective participation in adult life, does not, at least

94 Bronfenbrenner, 1976, p.9

95 Bronfenbrenner, 1976, p.231 
in American society, give high priority to providing opportunities in which such learning could take place. This would not be impossible to achieve. For some years I have been advocating the introduction in our schools, from the earliest grades onward, of what I have called a curriculum for caring [...]. The purpose of such a curriculum would be not to learn about caring, but to engage in it: children would be asked to take responsibility for spending time with and caring for others - old people, younger children, the sick, and the lonely ${ }^{96}$.

In this approach, sustainability becomes a question of mutual links and balance between life settings and forces influencing them. This emerges clearly in several of the many hypotheses Bronfenbrenner proposed, for instance hypothesis 38: "The developmental potential of a meso-system is enhanced to the extent that there exist indirect linkages between settings that encourage the growth of mutual trust, positive orientation, goal consensus, and a balance of power responsive to action in [sic] behalf of the developing person" ${ }^{97}$. It should be noted that the approach has a clear normative basis; certain qualities, such as caring attitudes and motivations, are assumed to be positive in a general sense.

Lack of sustainability in the sense indicated by the human ecology approach is common in education and takes many forms ${ }^{98}$. For instance, a public school system may have social justice as one of its official objectives, but at the same time distribute resources mostly on the basis of average student achievement. This can result in schools concentrating resources mainly on high-achieving students and leave the lowest achievers behind. Or a market-based higher education system with institutions at different levels in terms of teaching and research may become dominated by struggles for academic recognition and funding to such a degree that the broader mission of providing quality higher education for a wide segment of the population is undermined. Or the management of an education system may become so bureaucratic that the system is unable to respond to new needs for learning and skills which emerge in labour markets or society. The specific character of such problems depends on the historical trajectories and the dominant policy priorities in given societies, but at a more general level they represent failings in the ecosystems of education and society. They signal lack of sustainability because, if not corrected, they lead to the erosion - and in the end the breakdown - of edu-

96 Bronfenbrenner, 1976, p.53

97 Bronfenbrenner, 1976, p.216

98 Pretorius 2014, Whitty et al. 1998 cational logics.

One example of an ecological approach is a study of the interaction of schools and informal learning organisations in a regional context ${ }^{99}$. Jennifer Lin Russe11 and her colleagues use the concept of ecology as a metaphor to characterise the network of organisations in a locality which provide learning opportunities for youth, and argue that "By employing the language of ecology, we deliberately call attention to two properties: diversity and interdependence" ${ }^{\prime 100}$. In their view, the ecological perspective highlights two crucial properties of the regional education ecosystem: interdependence and diversity. In line with Bronfenbrenner, Russell and her colleagues see interdependence between micro-systems and other entities as a necessary quality, and they argue that this also applies to diversity. "Just as biodiversity is a measure of the health of an ecosystem, diversity in the organizational forms that provide organized educational activity in a region are indicative of a robust learning ecology" ${ }^{\prime 101}$.

For adult education, the balance and the interdependence necessary for sustainable development is often especially delicate. Adult education is generally the least institutionalised sector in educational systems. Establishing specific structures and institutions for adult education run by professional adult educators, and getting these recognised as part of the overall educational system, is necessary to provide stable opportunities for adult learning. But institutionalisation also involves the risk of separating education from the life situations and experiences of adult learners, thus "colonizing the life-world" ${ }^{102}$, which severely limits adult education's potential for developing a broad spectrum of vocational, social and personal capacities. A balance between institutional and non-institutional logics is essential to the sustainability of adult education systems. But balance here does not mean harmonious continuity. As discussed in the previous section, changes, innovations, and even conflicts, are necessary elements in social progress - both in education and elsewhere. But it is important that all actors consider the overall "ecology" of adult education and strive to make this sustainable.

In this paper, it is emphasised social sustainability

99 Russell et al. 2013

100 Russell et al. 2013, p.261

101 Russell et al. 2013, p.262

102 Habermas, 1981 
issues involved in education, especially adult education. But of course institutionalised education also interacts with the natural environment. For instance, schools, like other public buildings, emit greenhouse gases. In a 2008 report on this issue, the Sustainable Development Commission estimated that English schools emitted 8.5 million tonnes of carbon dioxide per year, and greenhouse gases equivalent to 9.4 million tonnes of carbon dioxide per year ${ }^{103}$. The "carbon footprint" of schools is composed of several sources: the use of energy in school buildings; travel and transport to and from schools by cars, trains and other means; supply chains of companies producing goods and services for schools; and schools' waste management ${ }^{104}$. The commission - which was closed in March 2011 by the Conservative coalition government - argued that emissions could be reduced dramatically if steps were taken without further delay.

Thus balance and interdependence, between the different social and educational "systems" where learning occurs and between these systems and their natural environments, are key elements of a sustainable ecology of adult education.

\section{Concluding Remarks}

Undoubtedly, sustainability and sustainable development are widespread conceptions today, and probably no one would contest they are "positive" ones. But their policy implications are not necessarily so, or at least they may become open to larger contestation when attention is focused on the role of adult education and learning policy in fostering societal sustainability, as it was tried to do in this contribution.

First, when are considered the conditions under which the concept of "sustainability", and by extension that of "sustainable development", entered the political debate, it is note that these were born out of a concern of how to secure potentially "endless economic growth" by controlling for the ecological footprint of humanity (i.e. taking into account both the use of natural resources and pollution produced by humankind) ${ }^{105}$. However, these concepts went hand in hand with preoc-

103 SDC, 2008, p. 3

104 SDC, 2008, p. 12

105 Meadows et al., 1972 cupations with the impact of the ecological footprint of humanity on future human co-existence ${ }^{106}$. From this perspective, while anthropocentrism has been strongly present in the interpretation of relations between mankind and the natural environment (i.e. natural resources only hold an extrinsic value for the benefit of humankind), education has been turned into a means for humankind to learn how to maximise (economic) benefit by taking care of the environment and its finite natural resources.

Second, despite the fact that the above views, and the implications they carry, are still en vogue, it is noted in some sectors of society, including education and environmental services, a growing awareness that this ontology of economic growth has silenced a number of other factors which concur with societal sustainability. Among them is the fact that the costs of maximising the benefit of humankind in the use of natural resources produce, rather than reduce, social conflicts, and that the costs of environmental pollution caused by certain societal groups, generations and countries are rarely reduced but rather borne by marginal groups, generations and countries.

It was also discussed the possibility of adopting an alternative ontology, emphasising societal (rather than economic) growth in ways which integrate the territorial, temporal and personal aspects of development ${ }^{107}$. In doing so, we also acknowledged that social and historical tendencies may produce unfair social relations, unless relations among social institutions are regulated to the scope of leveraging social inequalities, also among present and future generations ${ }^{108}$.

From this perspective, if we look at the history of adult education as a social institution, in its relations to social democratic welfare states, we note that it incorporates a paradox or tension between on the one hand making cultural "goods" available to ordinary people from every socioeconomic background, and on the other hand challenging the traditional cultural and social order. This tension, which is still present in welfare state provision for adult education today, must be confronted if adult education policy is to contribute to societal growth in sustainable ways.

Such a policy calls for looking at the ecology of edu-

\begin{tabular}{ll}
\hline 106 & Faure et al. 1972 \\
107 & Seghezzo, 2009 \\
108 & Rawls, 2001
\end{tabular}

108 Rawls, 2001 
cational systems, namely the mutual links education systems hold with multiple life-settings in which learners are embedded, as well as forces which influence these settings, and overarching institutions and structures of culture and society.

Developing frameworks for sustainability in adult education is no easy task, as our attempt in this paper surely shows. Combining frameworks for understanding social and natural environments and combining these with principles of social justice; conceptualising multiple balances without overlooking the potential dynamic change; transgressing anthropocentrism - all this is ambitious. It is emphasised that this perspective is not some kind of "grand theory", but rather a basic framework which could make it possible to navigate the shallows and the depths of the quest for societal sustainability, in research as well as in policy and educational practice.

\section{References}

Arrow, K., Bolin, B., Costanza, R., Dasgupta, P., Folke, C., Holling, C. S., et al. (1995). Economic growth, carrying capacity, and the environment. Ecological Economics, 15(2), 91-95.

Arrow, K. (1962). The economic implications of learning by doing. Oxford: The Review of Economic Studies, Oxford Journals

Baldi, U. (2011). The limits to growth revisited. New York: Springer.

Blewitt, J., \& Cullingford, C. (2004). The sustainability curriculum: The challenge for higher education. London: Earthscan.

Bronfenbrenner, U. (1976). The experimental ecology of education. Paper presented at the American Educational Research Association annual meeting, 19-23 April.

Bronfenbrenner, U. (1979). The ecology of buman development: Experiments by nature and design. Cambridge, MA: Harvard University Press.

Brown, T. (2013). Spatial and financial fixes and the global financial crisis: does labour have the knowledge and power to meet the challenge? International Journal of Lifelong Education,32(6), 690-704.

Castells, M. (2010). The Information Age: Economy, Society and Culture. 2nd ed. Oxford: Blackwell.
Elkington, J. (1997). Cannibals with forks: The triple bottom line of 21st century business. Oxford: Capstone Publishing Ltd.

Elsey, B. (2001). R H Tawney, patron saint of adult education. In P. Jarvis (Ed.), Twentieth-century thinkers in adult and continuing education (pp. 49-59). London: Kogan Page.

Faure, E., Herrera, F., Kaddoura, A. R., Lopes, H., Petrovski, A. V., Rahnema, M., et al. (1972). Learning to be: The world of education today and tomorrow. Paris: UNESCO.

Fisk, P. (2010). People, planet, profit: How to embrace sustainability for innovation and business growth. London: Kogan Page Publishers.

Habermas, J. (1981). The theory of communicative action: Reason and the rationalization of society (Vol. 1). Boston: Beacon Press.

Hobsbawm, E. (1975). The Age Of Capital: 1848 - 1875. New York: Vintage Books.

Hobsbawm, E. (1987). The Age Of Empire: 1875 1914. London: Weidenfeld \& Nicolson.

Hobsbawm, E. (1994). The Age Of Extremes: 1914 1991. New York: Pantheon Books.

Hobsbawm, E. (1962). The Age Of Revolution: 1789 1848. New York: World Publishing.

Lewis, C. T., \& Short, C. (1879). A Latin dictionary. Oxford: Clarendon Press.

Livingstone, D. W. (2012). Lifelong learning and lifewide work in precarious times: Reversing policymaking optics. In D. N. Aspin, J. Chapman, K. Evans, \& R. Bagnall (Eds.), Second international handbook of lifelong learning (pp. 269-286). Dordrecht: Springer.

Matthews, J. (2011). Hybrid pedagogies for sustainability education. Review of Education, Pedagogies, and cultural Studies, 33(3), 260-277.

McFarlane, D. A., \& Ogazon, A. G. (2011). The challenges of sustainability education. Journal of Multidisciplinary Research, 3(3), 81-107.

Meadows, D., Meadows, D., \& Jorgen Randers, J. (1972). The limits to growth: A report for the Club of Rome's project on the predicament of mankind. New York: Universe Books.

Milana, M. (2016). Global polity in adult education and UNESCO: Landmarking, brokering, and framing policy. Globalisation, Societies and Education, 14(2), 203-226.

Misiaszek, G. (2012). Transformative environmental 
education within social justice models: Lessons from comparing adult ecopedagogy within North and South America. In D. N. Aspin, J. Chapman, K. Evans, \& R. Bagnall (Eds.), Second international handbook of lifelong learning(pp. 423-440). Dordrecht/Heidelberg/London/ New York: Springer.

Myers, L. (2012). Sustainability education in classrooms. Green. Teacher, 98, 41-44.

Nussbaum, M. C. (2000). Women and buman development: The capabilities approach. Cambridge: Cambridge University Press.

Nussbaum, M. C., \& Sen, A. (Eds.). (1993). The quality of life. Oxford: Clarendon Press.

OED (Oxford English Dictionary) (2016). "sustainable, adj.”. OED Online. Oxford: Oxford University Press. http://www.oed.com/view/Entry/195210?redirected From=sustainable. Accessed 14 April 2016.

Pretorius, S. G. (2014). An education system's perspective on turning around South Africa's dysfunctional schools. Mediterranean Journal of Social Sciences, 5(15), 348-358.

Randers, J. (2005). What was the message of the Limits to growth? What did this little book from 1972 really say about the global future? Zurich: The Club of Rome. http:// www.flow.ph/1/limitstogrowth/What_was_the_message_of_Limits_to_Growth.pdf. Accessed 6 July 2016.

Rawls, J. (1971). A theory of justice. Cambridge, MA: Belknap Press of Harvard University Press.

Rawls, J. (1985). Justice as fairness: Political not metaphysical. Philosophy \& Public Affairs, 14(3), 223-251.

Rawls, J. (1993). Political liberalism. New York: Columbia University Press.

Rawls, J. (2001). Justice as fairness: A restatement. Cambridge, MA: Harvard University Press.

Russell, J. L., Knutson, K., \& Crowley, K. (2013). Informal learning organizations as part of an educational ecology: Lessons from collaboration across the formal-informal divide. Journal of Educational Change, 14, 259-281.

SDC (Sustainable Development Commission). (2008). Carbon emissions from schools: Where they arise and how to reduce them. Report. London, etc.: SDC. http://www.sdcommission.org.uk/data/files/publications/Publish_ Schools_Carbon_Strategy.pdf. Accessed 5 July 2016.

Sachs, J. (2015). The Age Of Sustainable Development.
New York: Columbia University Press.

Schumpeter, J. (1942). Capitalism, Socialism and Democracy. London:Routledge.

Seghezzo, L. (2009). The five dimensions of sustainability. Environmental Politics, 18(4), 539-556.

Sen, A. (1989). Development as capability expansion. Journal of Development Planning, 19, 41-58.

Sen, A. (1999). Development as freedom. New York: Knopf, 1999.

Sen, A. (1981). Poverty and famines. Oxford: Clarendon Press.

Simovska, V., \& Mannix McNamara, P. (Eds.). (2015). Schools for health and sustainability: Theory, research and practice. Dordrecht: Springer.

Singer, M. G. (2003). The ideal of a rational morality: Philosophical compositions. Oxford: Oxford University Press.

Singh, J. P. (2011). United Nations Educational, Scientific, and Cultural Organization (UNESCO): Creating norms for a complex world. London, New York: Routledge.

Solow, R. (1956). A contribution to the theory of economic growth. Oxford: Quarterly Journal of Economics, Oxford Journals.

Stiglitz, J., Greenwald, B. (2014). Creating A Learning Society. New York: Columbia University Press.

Tawney, R. H. (1964 [1931]). Equality. London: George Allen \& Unwin.

Tawney, R. H. (1966a [1914]). An experiment in democratic education. In R. Hinden (ed.), The radical tradition: Twelve essays on politics, education and literature by R.H. Tawney (pp. 74-85). Harmondsworth: Penguin.

Tawney R. H. (1966b [1953]). The Workers' Educational Association and adult education. In R. Hinden (ed.) The radical tradition: Twelve essays on politics, education and literature. R.H. Tawney (pp. 86-97). Harmondsworth: Penguin.

United Nations Educational, Scientific and Cultural Program - UNESCO (2015). Education 2030 Framework for Action. Incheon: United Nations Educational, Scientific and Cultural Program. Available at: http:// unesdoc.unesco.org/images/0024/002432/243278e. pdf Accessed 24 August 2016.

United Nations Environment Program - UNEP (2016). 6th Global Environment Outlook Report. Nairobi: 
United Nations Environment Program. Available at: http://www.unep.org/geo/ Accessed 24 August 2016.

UN (United Nations). (1992a). Rio declaration on environment and development. Annex 1 of the Report of the United Nations Conference on Environment and Development (UNCED, Rio de Janeiro, 3-14 June 1992). A/CONF.151/26 (Vol. I). New York: UN General Assembly. http://www.un.org/documents/ga/conf151/ aconf15126-1annex1.htm. Accessed 6 July 2016.

UN (1992b). Agenda 21. New York: UN. https://sustainabledevelopment.un.org/content/documents/Agenda21.pdf. Accessed 6 July 2016.

UN (1998). Kyoto protocol to the United Nations framework convention on climate change.New York: UN. http://unfccc. int/resource/docs/convkp/kpeng.pdf. Accessed 6 July 2016.

UNESCO (United Nations Educational, Scientific and Cultural Organization). (2009). Bonn declaration. Formulated at the UNESCO World Conference on Education for Sustainable Development held in Bonn, Germany on 31 March to 2 April. Bonn: UNESCO. http:// unesdoc.unesco.org/images/0018/001887/188799e. pdf. Accessed 5 July 2016.

WCED (World Commission on Environment and Development). (1987). Our common future [The Brundtland Report]. New York, NY: Oxford University Press.
WEA (Workers' Educational Association). (2013). A brief history of the Workers' Educational Association. London: WEA. https://issuu.com/weasheffieldwea/docs/ history_booklet?e $=1305752 / 1634711$. Accessed 5 July 2016.

WEA \& University of Oxford (1909). Oxford and working-class education: Being the report of a joint committee of university and working-class representatives on the relation of the university to the higher education of workpeople. 2nd edn. Oxford: Clarendon Press. Digitised facsimile of the first edition (1908) available at https://archive.org/stream/ oxfordworkingcla00workuoft\#page/8/mode/2up. Accessed 5 July 2016.

Webb, S. (2014). Using the experiences of skilled migrants to reflect on continuing education policies for workforce and sustainable development. Encyclopaideia, 18(40), 69-86.

Whitty, G., Power, S., \& Halpin, D. (1998). Devolution and choice in education: The school, the state and the market. Buckingham: Open University Press.

World Economic Forum (2016). The Global Competitiveness Report 2015 - 2016. [online] Geneve: World Economic Forum. Available at: http://www3.weforum.org/docs/Media/TheGlobalRisksReport2016.pdf Accessed 24 August 2016. 
Para publicar na Revista de Direito Internacional, acesse o endereço eletrônico www.rdi.uniceub.br ou www.brazilianjournal.org.

Observe as normas de publicação, para facilitar e agilizar o trabalho de edição. 